\title{
Studying exit from entrepreneurship: New directions and insights
}

\author{
Dawn DeTienne and Karl Wennberg
}

Linköping University Post Print

Tweet

N.B.: When citing this work, cite the original article.

Original Publication:

Dawn DeTienne and Karl Wennberg, Studying exit from entrepreneurship: New directions and insights, 2016, International Small Business Journal, (34), 2, 151-156.

http://dx.doi.org/10.1177/0266242615601202

Copyright: SAGE Publications (UK and US)

http://www.uk.sagepub.com/home.nav

Postprint available at: Linköping University Electronic Press

http://urn.kb.se/resolve?urn=urn:nbn:se:liu:diva-126820 


\title{
Studying exit from entrepreneurship: New directions and insights
}

\author{
Pre-print version of: \\ DeTienne, D., \& Wennberg, K. 2016. Studying exit from entrepreneurship: New directions and insights. \\ International Small Business Journal, 34(2): 151-156.
}

\author{
Dawn DeTienne \\ Colorado State University, USA \\ Karl Wennberg \\ Stockholm School of Economics, Sweden; \\ Institute of Analytical Sociology (IAS) at Linköping University, Sweden \\ Karl.wennberg@liu.se
}

\begin{abstract}
Research on entrepreneurial exit has established itself as a more recognized component of the entrepreneurial process and a distinctive domain of entrepreneurship research. Despite the progress made, there still exists important topics within entrepreneurial exit where scholarly understanding is scant. This special issue discusses new and open topics of research on entrepreneurial exit. Three papers examine three such topics including pricing intentions of exiting entrepreneurs, exit considerations among angel investors, and the relationship between exit and failure in new ventures.
\end{abstract}

Keywords: entrepreneurship, exit, failure, organizational dynamics, succession

Why is there so much research on new venture creation and growth and so little on the 'exit' stage of entrepreneurship? This was a question both of us struggled with when we met for the first time at the 2005 Babson College Entrepreneurship Research Conference. Many of our friends and contacts were active entrepreneurs and both of us had the experience of starting, growing, and exiting firms prior to our PhD research; thus, it struck us that entrepreneurship researchers seemed to have missed out on one of the most important phenomena in the entrepreneurial journey. As Howard Aldrich (2015, p.11) notes in his recent discussion of understanding exits in capitalist societies: "Entrepreneurial exit completes the full cycle of the entrepreneurial process, because every entrepreneurial entry carries the potential of becoming an entrepreneurial exit.” Time has moved swiftly and ten years later we have noted that research on entrepreneurial exit has blossomed beyond our expectations. Apparently, many other scholars 
agreed with our idea that the 'exit' stage of entrepreneurship was under-researched, undertheorized, and in need of more attention.

The timeliness of this emerging stream of research to the state of entrepreneurial practice around the globe could not have been better. The financial crises, which began in 2008, generated interest among both scholars and policy makers regarding the differences between entrepreneurs and firms that fail and those that complete an exit. The stark differences between conducting a successful exit and exiting in financial distress became even more apparent as we saw capital markets and the M\&A market for small-and medium-sized firm collapse as well. However, in 2014, according to PricewaterhouseCoopers (PwC), global merger and acquisition activity began again to rise and ultimately hit $\$ 3.5$ trillion USD (up 47\% from 2013). The volume and value of IPOs in the U.S. is also on the rise in Europe, Asia, and the United States. Some argue that this is due to a pent-up supply of high-growth entrepreneurs and firms that were waiting for a healthier economy to seek an exit. Coinciding with this is the impact of the many family firms started by the baby boomer generation, many of whom are now reaching retirement age and seek to divest of their firm or find a successor. Certainly low interest rates, the strength of the private equity market, and the use of start-ups as a funnel for innovation in larger firms has impacted the market as well.

However, it is important to remember that entrepreneurial firms have always exited the market at an astonishing rate. As David Audretsch argues convincingly in his 'revolving door hypothesis' (Audretsch 1995), the number of exiting firms in an economy is always almost at par with the number of new entrants. While some might argue that these firms "failed", the emerging research demonstrates that entrepreneurs end their firms for a myriad of reasons including retirement, a desire to recapture the initial investment (harvest), family reasons, personal reasons such as health and motivation, or to take advantage of another opportunity either as an employee or by starting yet another new venture.

At this point it is thus important to reiterate that entrepreneurial exit can take many forms, which is a key focus in management oriented research on exits. The entrepreneur may exit an ongoing entity which is often referred to as succession. This topic has been well-addressed in the large, global firm and within the family business literature although we certainly know less about the 
exit of entrepreneurs from the micro, small, and middle market. The entrepreneur may choose to close down the firm and leave entrepreneurship entirely. Many have referred to this as "firm exit" or "business exit." There exists a body of literature examining this topic although one must be careful when examining this literature to clarify how exit is operationalized. If it is operationalized as failure, but the researchers did not include financial data, we must be careful to generalize this literature. Statistics suggest that between 80 to 95 per cent of firms that fail are of this type. In other words, pre-emptive voluntary exits of underperforming firms are by far more common than firms becoming insolvent and set into bankruptcy (Thorburn 2000; Wennberg et al. 2010). Additionally, the entrepreneur may choose to close down a single firm, but may remain involved in entrepreneurship though other ventures (i.e. portfolio entrepreneurs) or through a new start-up (Westhead and Wright 1998). The important similarity among these forms is that entrepreneurial exit refers to a volitional, cognitive decision-making process that is not purely financial in nature. That is, individuals make voluntary exit decisions and understanding these decisions is critical to our understanding of entrepreneurship.

Also it is important to note that entrepreneurial exit is not as clear as the above statements may imply as entrepreneurs who complete an IPO often remain part of the Board of Directors and may only dilute their financial shares over time. Some who complete an acquisition stay on with the firm in a management role (are they entrepreneurs?) and those who transfer a firm to the next generation often retain some control until their demise. Thus, control and financial investment are two important components that should be considered when examining "entrepreneurial exit". Clearly it would be "convenient" if all individuals who exited gave up complete control and all financial interest in the firm; however, this is where the really interesting questions come to bear in this research.

Research on entrepreneurial exit has established itself as a more recognized component of the entrepreneurial process and a distinctive domain of entrepreneurship research, as indicated in recent publications, monographs, special issues and keywords and domains noted in the entrepreneurship field journals. This emerging research has brought a host of new and debated topics. Some of these topics were, to us, quite novel and related to aspects we had never considered. As such, it seemed timely to gather stock of the global exit research by scholars 
from various disciplines. We therefore initiated an open call to scholars from around the globe to submit papers for an interdisciplinary conference on exits. Thanks to a generous grant from the Marcus Wallenberg Foundation we were able to organize an international conference at the Ratio Institute in Sweden in the fall of 2013, with professors Howard Aldrich and Susan Marlow as keynote speakers.

This Special Issue on Entrepreneurial Exit and a recent companion Research Handbook (DeTienne and Wennberg 2015) is a result of papers presented at the conference together with pieces submitted through a competitive open call to the scholarly community, all which were processed through ISBJ' double-blind peer review process with several iterations. The Special Issue includes three rigorous papers of both conceptual and empirical nature. In summary, the three articles in this special issue all examine unique topics including pricing intentions of exiting entrepreneurs, exit considerations among angel investors, and the relationship between exit and failure. Specifically, the study by Mason and Botelho examines the relative salience of exit among business angels. Their study explicitly addresses the empirical puzzle that while business angels frequently suggest that the difficulties in achieving timely and profitable exits is the most pressing problem for investors, many business angels maintain that consideration of future exit potential is a key focus in their investment decisions. The relative scarcity of profitable exits and the frequently long time horizon to exit may have a negative impact on the level of future business angel investment activity. Mason and Botelho's study explicit exit strategies propagated by 21 'gatekeepers' - those who represent business angel groups in Scotland and Northern Ireland. While these gatekeepers maintain that exit considerations are important for their investment decisions, this is contradicted by verbal protocol analysis of questions in their initial screening process of potential investments. In other words, the explicit goals of many business angels are not aligned with their strategies, a well-known myopic problem in strategic management and entrepreneurship research (Maxwell et al. 2011; Shepherd 1999) Thus, Mason and Botelho conclude that business angels and other investors may benefit by adopting more "exitcentric" approaches to investing.

The study by McKelvie and Jenkins discusses the conceptual and theoretical underpinnings of research into entrepreneurial failure. They note a lack of clarity surrounding how failure is 
conceptualized, influencing the type of research questions posed as well as comparability of findings across studies (c.f. Coad 2013). McKelvie and Jenkins specifically review and discuss predominant conceptualizations of entrepreneurial failure at two distinct levels of analysis (firm and individual) and whether failure is operationalized based on objective (performance-based) or subjective (perception-based) criterion. These distinctions carry important implications for conclusions that are drawn and their generalizability, since firm-level objective criteria such as bankruptcy or insolvency means that the many firms in a 'grey zone' of low or no profitability are excluded (Ucbasaran et al. 2013). On the other hand, conceptualizations of failure based on the subjective criterion means that more heterogeneous samples of entrepreneurs or firms will be included, and delineation of relevant sample populations may be more difficult to outline and replicate. McKelvie and Jenkins conclude that two areas of interest in entrepreneurial failure research - the roles of emotions and learning among failed entrepreneurs - may carry specific implications depending on whether objective or subjective definitions of failure are used. They further suggest that research on projects and project failure may be of relevance to future research since entrepreneurs have been noted to pursue multiple business opportunities or even run several firms simultaneously, potentially valuing them as part of a bundle with different riskreturn trade-offs (Davidsson 1989; Westhead and Wright 1998).

The study by Kammerlander examines price expectations among managers of Swiss SMEs who are considering selling their firms and compare these expectations to those who have recently sold their firms. In doing so, Kammerlander develops the term emotional pricing which is defined as those elements of the founder-managers' price expectations that cannot be traced back to economic considerations (such as net present value of assets and activities in the firm). Drawing on research in behavioural finance and family business, she hypothesize that an “emotional price discount” will be more common among entrepreneurs with long tenure in their firms, among entrepreneurs who are familiar with the new owner, and among entrepreneurs whose firms are not performing as expected. Hypotheses are tested using data on exit intentions and price expectations among 1,354 founder-managers of Swiss SMEs, as well as data on 455 actual ownership transfers in similar firms. 
Kammerlander's study - pioneering in its kind and focus on both perceived and actual pricing discounts among M\&A privately-held firms - shows strong support for the existence of foundermanagers' "emotional pricing” when they wish to sell their firms to successors. The theoretical mechanism argued as triggering such emotional price discounts are (i) managers reluctance to lose access to information about and influence on the firm, and (ii) founder-managers' aversion to putting the firm's future at unduly risk. Her study extends previous research suggests that founder-managers are emotionally attached to their firm by showing that founder-managers also care about the firms' post-exit prosperity and are willing to forego optimal price to ensure the firm is acquired by what they judge as a good new owner. Kammerlander's research has implications for research on entrepreneurial exit as well as research on entrepreneurial emotions, a field that has often adopted a 'parenting metaphor' when it comes to founder-managers' emotional relationship to the firms they create (Cardon et al. 2005). In other words, Kammerlander's research shows that firms that are sold are sometimes considered "adult offspring” by entrepreneurs seeking to ensure, even beyond their own management, the continuation of the firms they created.

Taken together, the three papers provide fresh insights for scholars in entrepreneurship and others interested in the phenomenon of entrepreneurial exit. These papers serve to fill significant research gaps in research on entrepreneurial exit. Still, the lion's share of empirical studies have examined exit of rather large private businesses from the market or a specific sector, ignoring the fact that most exits are in fact conducted in rather small firms governed by a single ownermanager entrepreneur. Among somewhat larger firms, venture capitalists and other investors often play crucial roles in both timing, and execution of exit processes. As such, the papers by Mason and Botelho as well as Kammerlander in this special issue adds to the scholarly understanding of how both firm founders and investors develop exit strategies and set expectations of what is considered a successful exit. These studies provide important food for thought for the academic disciplines of finance, accounting and behavioral economics, as well as interdisciplinary studies of entrepreneurial exit.

Further, theoretical perspectives on the various dimensions of failed and successful exits are provided in the paper by McKelvie and Jenkins, suggesting important room for discipline- 
oriented research in psychology, sociology, and organization theory, as well as interdisciplinary studies of entrepreneurial exit. Disentangling the various dimensions of exit (including 'failure' from 'successful' exit) is important since the ramifications of exit may differ across internal and external stakeholders such as founders, investors and employees. As editors and scholars of entrepreneurial exit, we see vast room for additional empirical research to operationalize and scrutinize the insights offered by McKelvie and Jenkins.

Despite the progress made in the last ten years or so, there still remains a myriad of important topics within entrepreneurial exit for which scholars lack an understanding. Examples include processual studies on the development of exit strategies - including how negotiations are conducted (Gersick 1994), psychological and cognitive barriers to exit among founders and other stakeholders, international/comparative studies of exits in various institutional environments, studies which further the formation of valuation expectations and pricing models from both seller's and acquirers' perspective, and finally macro-level implications of exit on institutions, philanthropic infrastructure or economic development (Mason and Harrison 2006).

One open question for research on exiting entrepreneurs remains their motivation to leave their current business. It is easy to conceive of emotional factors perceived either as positive or as negative for founder-managers choice to exit. These might include creation of a new venture, returning to wage employment, returning to education, or a multitude of other potential opportunities. As a research field, we still have limited understanding of these factors and why entrepreneurs might leave a successful venture. Psychologists, sociologists and scholars in organization theory may take an interest in such positive or negative emotions related to exit. Is it simple boredom? The need for a challenge? The need to contribute to society in a different manner? The desire to create rather than to manage? Family issues? Economists, political scientists, and geographers may be interested in the macro-side of exits and how they relate to contextual conditions: How are exits and exit rates related to institutional factors (potentially unobserved by the layman) such as increasing regulatory impact, globalization, or changes in tax laws? 
All in all, there remains much to be done in studies of entrepreneurial exit before this area has provided an understanding on par with what we know about new startups or new venture growth. We hope the special issue will be useful for researchers in the domain of entrepreneurship and small business at large and especially for research related to entrepreneurial exit.

\section{References}

Aldrich Howard (2015) Perpetualy on the eve of destruction? Understanding exits in capitalist socieities at multiple levels of analysis. In D. DeTienne \& K. Wennberg (Eds.), Research Handbook of Entrepreneurial Exit (pp. 11-42). Cheltenham: Edward Elgar.

Audretsch David B. (1995) Innovation and industry evolution. Cambridge, Mass. ; London: MIT Press.

Cardon Melissa S, Zietsma Charlene, Saparito Patrick, Matherne Brett P and Davis Carolyn (2005) A tale of passion: New insights into entrepreneurship from a parenthood metaphor. Journal of Business Venturing 20(1): 23-45.

Coad Alex (2013) Death is not a success: Reflections on business exit. International Small Business Journal.

Davidsson Per (1989) Continued entrepreneurship and small firm growth. Stockholm: Economic Research Institute Stockholm School of Economics Ekonomiska forskningsinstitutet vid Handelshögsk. (EFI).

DeTienne Dawn R and Wennberg Karl (Eds.). (2015). Research Handbook of Entrepreneurial Exit: Edward Elgar Publishing.

Gersick Connie JG (1994) Pacing strategic change: The case of a new venture. Academy of Management Journal 37(1): 9-45.

Mason Colin M. and Harrison Richard T. (2006) After the exit: Acquisitions, entrepreneurial recycling and regional economic development. Regional Studies 40(1): 55-73.

Maxwell Andrew L, Jeffrey Scott A and Lévesque Moren (2011) Business angel early stage decision making. Journal of Business Venturing 26(2): 212-225.

Shepherd Dean A (1999) Venture capitalists' assessment of new venture survival. Management Science 45(5): 621-632.

Thorburn K.S. (2000) Bankruptcy auctions, costs, debt recovery, and firm survival. Journal of Financial Economics 58: 337-368.

Ucbasaran D., Shepherd D.A., Lockett A. and Lyon S.J. (2013) Life after business failure: The process and consequences of business failure for entrepreneurs. Journal of Management 39(1): 163-202.

Wennberg K., Wiklund Johan, DeTienne D. and Cardon M. (2010) Reconceptualizing entrepreneurial exit: Divergent exit routes and their drivers. Journal of Business Venturing 25(4): 361-375.

Westhead Paul and Wright Mike (1998) Novice, portfolio, and serial founders: are they different? Journal of Business Venturing 13(3): 173-204. 